\title{
ERGONOMIC RISK FACTORS AND MUSCULOSKELETAL DISORDERS (PREVALENCE \& COST) AMONG WORKERS IN A MULTINATIONAL CAR ASSEMBLY PLANT, EGYPT
}

\author{
By \\ Alazab R. M. \\ FROM \\ Public health and Industrial medicine Department, Faculty of medicine, \\ Alazhar Uiversity, Cairo, Egypt
}

\begin{abstract}
Objectives: to define the magnitude of the ergonomic stressors related to neck and trunk posture, energy expenditure and upper extremity among workers in the studied plant, to find out the incidence rate of work injuries resulted from ergonomic causes among the studied workers and to find out the prevalence rate and cost of musculoskeletal disorders among the studied workers. Subjects \& Methods: this study was conducted inside a multinational factory in Egypt for car assembly. 553 workers were included in the study. All workers were subjected to checklists to monitor the different ergonomic stressors during their daily work. Environmental measures were conducted through coordination with National Institute of Occupational Safety and Health (NIOSH), Egypt. Data about distribution and cost of MSDs were obtained from the medical recording system inside the medical department of the factory. Results: noise, ultraviolet rays, vibration and carbon monoxide in body shop while heat and thinner in paint shop were above the permissible level. $21.7 \%, 3.2 \%$ and $27.6 \%$ of workers were standing stationary, kneeling and knee bent respectively. Trunk posture revealed that $43.1 \%, 11.8 \%$ and $49.2 \%$ of workers were doing forward bending, backward bending and lateral bending respectively. Neck posture revealed that $29.7 \%, 13.8 \%$ and $17.2 \%$ of workers were doing forward bending, backward
\end{abstract}


bending and lateral bending respectively. About $11 \%$ were doing sit/stand position. Energy expenditure assessment revealed that; 12.1 of workers in their jobs need to walk more than $30 \mathrm{~m}^{2} / \mathrm{M}$ while carrying weights. Upper extremity stressors revealed that $36.7 \%$ were doing repetitive work, $14.2 \%, 7.1 \%$ and $13.5 \%$ were gripping on object with slippery surface, tip of a finger used for pressing and gloves hinder the grip respectively. $11.3 \%$ and $5.1 \%$ of workers were pushing or pulling objects weight $>300 \mathrm{gm}$ by one hand repeatedly and hold repeatedly an object which weighs more than $200 \mathrm{gm}$ in one hand respectively. $7.4 \%$ and $15.6 \%$ were using pinch grip and using rotating motion of the forearm respectively. $3.9 \%$ were exposed repeatedly to vibrating tools. It was found that; incidence rate of work injuries/100 workers/one year was (1.2) and the prevalence rate of MSDs was (23.7\%). About $43 \%$ of the ergonomic core requirements were fully implemented inside the studied plant. It was estimated that the cost of MSDs/person/year 2006 was about 7300 L.E.(1281\$). Conclusion: MSDs of neck was strongly associated with combined neck ergonomic stressors. Hand/Arm pain was strongly associated with repetitiveness and pushing forces. Lumbosacral disorders were strongly associated with combined trunk ergonomic stressors. The prevalence rate of MSDs was 23.7\% and cost of MSDs/ person/ year 2006 was about 7300 L.E. (1281\$).

\section{Introduction}

Vehicle manufacture of cars in particular is a major industry worldwide accounting for at least $7 \%$ of the manufacturing workforce in countries as diverse as the United States, Canada, Mexico, Brazil, Sweden, Spain, Japan, India, and Australia. (Fransson et al., 1996).

In Egypt, there are 21 companies working in the industry of vehicle assembly. About 72000 vehicles and 87000 vehicles were assembled in Egypt during the year 2005 and 2006 respectively. These vehicles include cars, buses, Microbuses and pickups. The assembly of the vehicles depends on imported materials and also national materials. Therefore, there are companies for the assembly of cars and other companies for manufacturing the needed materials (Ministry of industry, 2007).

It was anticipated that there are multiple physical stressors present in each vehicle plant. Specifically repetitive machine paced tasks, various postural stresses, forceful exertions, segmental vibration exposures, contact mechanical stresses and other exposures likely to occur among jobs in different plants (Punnet, 1998).

Musculoskeletal disorders due to biomechanical overload play a significant socioeconomic role as they represent one of the major causes of disability and conse- 
quent absence from work. The risk factors of these disorders are multifactorial and present aspects which have not been fully clarified and explored (Mattioli et al., 2006).

Severe and non-fatal injuries often require hospitalization. These injuries have the highest potential of resulting in both short-term and long-term disability and are among the most costly of all injuries from an economic perspective. Also, work related injuries involve substantial loss of productivity for the injured worker. Studies on cost of injuries are important for providing information on: the economic burden of injuries, the comparison of cost burdens of different injuries and diseases, the cost to be incorporated into costeffectiveness analysis and prevention efforts and the trends in costs and projection of future costs (Weil, 2001).

The main hypothesis in this study was that unfavorable ergonomic conditions and factors related to work technique are risk factors for workers with musculoskeletal symptoms.

\section{Objectives}

- To define the magnitude of the ergonomic stressors related to different postures, energy expenditure and upper extremity among workers in the studied plant.
-To find out the incidence rate of work injuries resulted from ergonomic causes among the studied workers.

-To find out the prevalence rate and cost of musculoskeletal disorders among the studied workers.

\section{Subject and Methods}

\section{Research setting:}

This study was conducted within 12 months inside a multinational company for automobile assembly. The plant is situated in 6 October city, Giza governorate, Egypt. The plant was constructed since about 25 years for assembling cars, vans, and pickups. About 120 vehicles are the daily products of the company. The workplace is divided into two big distinct units: Body shop and Painting shop. The Body shop is subdivided into different stations starting with receiving the materials and end with forming the shell of the vehicle. The main hazards inside the workplace of the body shop include ergonomic hazards, noise and chemical hazards mainly during the processes of welding. The automobile body from the body shop enters the paint shop on a conveyer where it is degreased; layers of paint are applied and then cured in an oven. The main hazards in paint shop are noise and fumes. 


\section{Study design:}

Cross sectional study was designed to find a baseline data about the magnitude of the ergonomic problems inside the studied plant prior to a project for an intervention. The indicators of this study were; percentage of musculoskeletal disorders among the workers participated in this study, incidence of work injuries resulted from ergonomic cause among the studied workers and number of ergonomic core requirements fully implemented inside the studied plant. This study passed 3 phases: preparatory phase (during which site of the study, target population, preparation of checklists, pilot study, sampling and ethical consideration were done), Implementation phase (during which data collection was done) and evaluation phase (during which data entry, statistical analysis, results, discussion, conclusion and recommendations were done).

\section{Target population:}

(553) were included in this study. 312 workers from body shop and 241 workers from paint shop. Officially, the plant is working only one shift/day for 5 days/ week. Each shift is 8 hours/day. Under certain circumstances and due to work needs (increase the production to meet the market needs) the working days extend to be 6 days / week and the working hours extend to be 10 hours / day.

\section{Data Collection, methods and statistical analysis:}

Personal data including age, sex and special habits were collected. Occupational history including type of occupation, duration of occupation, working hours/day, working days/week, nature of exposure and past history of other occupations were collected. History of musculoskeletal disorders and history of injuries were collected. Checklists to assess the environmental measures inside the workplace (noise, heat, ultraviolet radiation, vibration, carbon monoxide and thinner) were conducted. These measurements were done during year 2006 by NIOSH, Egypt. Posture of general body /legs, trunk, neck and seat were assessed by using checklist modified from (NIOSH, 1997). Energy expenditure was assessed by using checklist modified from ( Bhattacharya et al., 1996). Posture of upper limb was assessed by using checklist modified from ( Keyserling et al., 1992), (Keyserling et al., 1993) and (Lifshitz and Armstrong, 1986). Incidence rate of injuries/100 full time workers/year was calculated based on the following equation: [Number of new cases during a time period x 200,000 hours / Total hours worked by all workers for the time period]( Kuorinka and Forcier, 1995). All cases of MSDs were diagnosed after referral 
to consultants of orthopedics and neurosurgery. Computerized Tomography (C.T.), Magnetic Resonant Imaging (MRI), Xrays and electrophysiological tests were the investigations used to prove the diagnosis of MSDs. Cost of musculoskeletal disorders was estimated based on; medical cost, wage losses and associated cost (Waehrer et al., 2004). The ergonomic core requirements inside the studied plant were assessed by using modified check list (Kroemer, 1997). The checklists were filled by the researcher while monitoring the nature of the work of each worker included in the study. Data entry and statistical analysis were done by using personal computer (Epi info program). Proportion, $\mathrm{z}$ test, $\mathrm{chi}^{2}$, and correlation coefficient were the statistical methods used for analysis of data. $\mathrm{P}$ value $<0.05$ was accepted as a level of significance.

\section{Results}

Table (1) shows the general characteristics of the studied workers. It was found that about $52 \%$ of body shop workers and about $57 \%$ of paint shop workers were smokers without statistical significant difference. There was no statistical significant difference as regards age groups among the studied workers in body shop group and paint shop group. There was no statistical significant difference as regards duration of work among the studied workers in body shop and paint shop. Mean working hours/week was 56 hours among workers in both groups. Environmental physical measures inside the workplace revealed that; noise level (99.3dB) was above Time Weighted Average (TWA) in body shop while in paint shop it was within TWA (83.4dB). Heat was above TWA in paint shop $\left(29.7 \mathrm{C}^{\circ}\right)$ while it was within TWA in body shop. Vibration was above TWA in body shop $(5 \mathrm{~Hz} / \mathrm{s})$ while there was no vibration hazard in paint shop. Ultraviolet rays were above TWA $(0.5 \mathrm{~m}$ watt $/ \mathrm{cm}^{2}$ ) in body shop while there was no ultraviolet hazard in paint shop. It was measured that thinner $\left(791.7 \mathrm{mg} / \mathrm{cm}^{2}\right)$ in paint shop and carbon monoxide (35PPM) in body shop were above TWA.

Table (2) shows the results of monitoring of the different body postures and energy expenditure among the studied workers. It was shown that; $31.1 \%, 17.9 \%$ and $4.2 \%$ of body shop workers were, knees bent, standing stationary and kneeling respectively while among paint shop workers the percentages were $23.2 \%, 26.5 \%$ and $2.1 \%$ respectively with statistical significant difference. Regarding trunk posture, it was shown that $55.4 \%, 16.9 \%$ and $61.2 \%$ of worker in body shop were doing forward bending $<45^{\circ}$, backward bending 
$>20^{\circ}$ and twisting $>20^{\circ}$ respectively while among worker in paint shop, the percentages were $25.7 \%, 4.9 \%$ and $33.6 \%$ respectively without statistical significant difference. As regards neck posture, it was found that $37.5 \%, 18.9 \%$ and $19.5 \%$ of workers in body shop were doing work needing forward bending $>20^{\circ}$, backward bending $>20^{\circ}$ and twisting $>20^{\circ}$ respectively while among workers in paint shop the percentages were $19.5 \%, 7.05 \%$ and $14.1 \%$ respectively without statistical significant difference. Concerning seated posture, it was noticed that $14.1 \%$ of body shop workers were using sit/stand posture while only $7.9 \%$ of workers in paint shop were using that posture with statistical significant difference. Regarding energy expenditure, it was found that $13.5 \%$ of workers in body shop were subjected to work need walk $>30 \mathrm{~m}^{2} /$ Minute while carrying weight $>150 \mathrm{gm}$ while $9.9 \%$ of workers in paint shop were needing to do the same job. It was found that; $4.8 \%$ of workers in body shop were subjected to work needing them to climb up and/or down repeatedly while only $2.5 \%$ of workers in paint shop were doing the same job. It was shown that only $4.9 \%$ of workers in paint shop were wearing the respirator.

Table (3) shows the state of upper extremity movements during work of the studied workers. It was shown that $30.4 \%$ of body shop workers and $37.7 \%$ of paint shop workers were subjected to repetitive use of the hands and/or wrists without statistical significant difference. Regarding mechanical stress it was shown that $9.9 \%$ and $4.9 \%$ of workers in body shop and paint shop respectively were using palm like a hammer without statistical difference. $2.9 \%$ and $2.5 \%$ of workers in body shop and paint shop respectively were subjected to work needing to put localized pressure on finger or thumb. Regarding forces; It was shown that; $18.3 \%$ and $9.1 \%$ of workers in body shop and paint shop respectively were in need to grip an object. $15.7 \%$ and $10.8 \%$ of workers in body shop group and paint shop group respectively were wearing gloves and the gloves hinder gripping. $13.5 \%$ and $8.7 \%$ of body shop group and paint shop group respectively were pushing or pulling objects weight $300 \mathrm{gm}$ by one hand with no statistical significant difference. Regarding posture; $32.7 \%$ and $14.9 \%$ of workers in body shop and paint shop respectively were subjected to work need twisting of the forearm without statistical significant difference. As regards tools; it was found that only $7 \%$ of workers in body shop were exposed to vibration from the used tools. 
Table (4) shows that head injuries were predisposed with ergonomic problem linked to neck forward, bending, lateral bending, backward bending and twisting. Injuries affecting the thumb were predisposed to use of hand for pushing and using of thumb as a tool to press. Injuries affecting the hand were predisposed with repetitive use of hand and putting a localized pressure on the palm of the hand. Injury affected the finger was predisposed to repetitive use of the hand. It was calculated that the incidence rate of work injuries due to ergonomic causes /100 workers/ year 2006 was 1.2 .

Table (5) shows the prevalence rate of musculoskeletal disorders among the studied workers. It was shown that $23.7 \%$ of the studied workers were affected with musculoskeletal disorders. It was noticed that cervical disc prolapse and lumbosacral disc prolapse $(38.9 \%$ and $43.5 \%$ respectively) were the most common prevalent disorders among the workers with MSDs while they represent $9.2 \%$ and $10.3 \%$ respectively among the total examined workers. It was noticed that $23.7 \%, 23.7 \%$, $11.4 \%$ and $10.7 \%$ of workers with MSDs were suffering osteoarthritis, hand/arm pain, carpal tunnel syndrome and tennis el- bow respectively. Also, this table shows that there was no statistical significant difference between the prevalence rate among body shop and paint shop groups as regards MSDs.

Table (6) shows the estimated cost of musculoskeletal disorders/person/year among the affected workers. It was shown that the total medical cost was 133560 L.E., total cost of wage losses was 354233 L.E. and associated cost was 473220 L.E. The average cost of musculoskeletal disorders/person/year was 7335.98 L.E (1287\$).

Table (7) shows that $42.8 \%, 28.6 \%$ and $28.6 \%$ of the ergonomic core requirements were fully implemented, partially implemented and not implemented respectively.

Table (8) shows the correlation between ergonomic risk factors and MSDs. It was noticed that; cases with lumbosacral disc prolapse were moderately correlated $(\mathrm{r}=0.7)$ with trunk posture. Cases with cervical disc prolapse were moderately correlated $(r=0.6)$ with neck posture. Cases with Hand/Arm pain were strongly correlated $(\mathrm{r}=0.8)$ with repetitiveness and moderately correlated $(r=0.6)$ with the use of forces. 
Table (1): General characteristics of the studied workers and Environmental measures inside the studied workplace

\begin{tabular}{|c|c|c|c|c|}
\hline \multirow[t]{3}{*}{ General Characteristics } & \multicolumn{4}{|c|}{ Total number $=553$} \\
\hline & \multicolumn{2}{|c|}{$\begin{array}{l}\text { Body Shop } \\
(\mathrm{N}=312)\end{array}$} & \multicolumn{2}{|c|}{$\begin{array}{l}\text { Paint Shop } \\
(\mathrm{N}=241)\end{array}$} \\
\hline & $\mathrm{N}$ & $\%$ & $\mathrm{~N}$ & $\%$ \\
\hline $\begin{array}{ll}\text { Age (years): } & \\
24- & \\
34- & \\
44-53 & \\
\text { chi }^{2}=1.2 \quad \mathrm{P}=0.6\end{array}$ & $\begin{array}{c}21 \\
137 \\
154\end{array}$ & $\begin{array}{c}6.7 \\
43.9 \\
49.4\end{array}$ & $\begin{array}{l}14 \\
97 \\
130\end{array}$ & $\begin{array}{l}5.9 \\
40.2 \\
53.9\end{array}$ \\
\hline $\begin{array}{l}\text { Sex: } \\
\text { Male }\end{array}$ & 312 & 100.0 & 241 & 100.0 \\
\hline $\begin{array}{l}\text { Special habit: } \\
\text { - Smoker } \\
\text { - Non smokers } \\
\text { chi }^{2}=1.2 \quad \mathrm{P}=0.3\end{array}$ & $\begin{array}{l}163 \\
149\end{array}$ & $\begin{array}{l}52.2 \\
47.8\end{array}$ & $\begin{array}{l}137 \\
104\end{array}$ & $\begin{array}{l}56.8 \\
43.2\end{array}$ \\
\hline $\begin{array}{l}\text { Duration of work (years): } \\
5- \\
10- \\
15- \\
20-22 \\
\operatorname{chi}^{2}=3.7 \quad \mathrm{P}=0.3\end{array}$ & $\begin{array}{l}27 \\
81 \\
72 \\
132\end{array}$ & $\begin{array}{l}8.7 \\
25.9 \\
23.1 \\
42.3\end{array}$ & $\begin{array}{l}13 \\
54 \\
64 \\
110\end{array}$ & $\begin{array}{c}5.4 \\
22.4 \\
26.6 \\
45.6\end{array}$ \\
\hline Mean working hours/week & & & & \\
\hline $\begin{array}{l}\text { Environmental measures: } \\
\text { Noise }\left(\mathrm{TWA}^{*}:<85 \mathrm{~dB}^{* *}\right)\end{array}$ & & & & \\
\hline Heat (TWA:26.7Cº & & & & \\
\hline Vibration (TWA:4 Hertz/second) & & & & \\
\hline Ultraviolet rays (TWA:0.1micro watt $/ \mathrm{cm}^{2}$ ) & & & & \\
\hline Thinner (TWA: $565.4 \mathrm{mg} / \mathrm{m}^{2}$ ) & & & 791 & $\mathrm{~m}^{3}$ \\
\hline Carbon monoxide (TWA: 25PPM) & & & & \\
\hline
\end{tabular}

*Time Weighted Average (TWA): was accepted according to decision NO.211, year 2003, Ministry of Manpower, Egypt

**: According to the company regulations; noise should not exceed $85 \mathrm{db}$ inside the workplace 
Table (2): Monitoring of different postures and energy expenditure among the studied workers

\begin{tabular}{|c|c|c|c|c|c|c|}
\hline \multirow[t]{2}{*}{ Posture } & \multicolumn{2}{|c|}{$\begin{array}{l}\text { Body shop } \\
(\mathrm{N}=312)\end{array}$} & \multicolumn{2}{|c|}{$\begin{array}{l}\text { Paint shop } \\
(\mathrm{N}=241)\end{array}$} & \multicolumn{2}{|c|}{$\begin{array}{c}\text { Total } \\
(\mathrm{N}=553)\end{array}$} \\
\hline & $\mathrm{N}$ & $\%$ & $\mathrm{~N}$ & $\%$ & $\mathrm{~N}$ & $\%$ \\
\hline General Body Posture/Legs: & 56 & 170 & 64 & 265 & 120 & 217 \\
\hline $\begin{array}{l}\text {-Standing stationary on an unpadded } \\
\text { floor surface. }\end{array}$ & - & - & - & - & - & - \\
\hline -Using a foot pedal while standing. & - & _ & - & - & - & - \\
\hline -Lying on back or side. & - & - & - & - & - & - \\
\hline -Kneeling. & 13 & 4.2 & 5 & 2.1 & 18 & 3.2 \\
\hline $\begin{array}{l}\text {-Knees bent or squatting. } \\
\text { chi }^{2}=\mathbf{9 . 5} \mathbf{p}=\mathbf{0 . 0 0 8} *\end{array}$ & 97 & 31.1 & 56 & 23.2 & 153 & 27.6 \\
\hline $\begin{array}{l}\text { Trunk Posture: } \\
\text {-forward bending }<45^{\circ}\end{array}$ & 173 & 55.4 & 62 & 25.7 & 235 & 43.1 \\
\hline -forward bending $>45^{\circ}$ & - & - & - & - & - & - \\
\hline -Backward bending $>20^{\circ}$ & 53 & 16.9 & 12 & 4.9 & 65 & 11.8 \\
\hline $\begin{array}{l}\text {-Twisting }>20^{\circ} \\
\mathbf{c h i}^{\mathbf{2}}=\mathbf{3 . 5} \mathbf{p}=\mathbf{0 . 2}\end{array}$ & 191 & 61.2 & 81 & 33.6 & 272 & 49.2 \\
\hline Neck Posture: & & & & & & \\
\hline - forward bending $>20^{\circ}$ & 117 & 37.5 & 47 & 19.5 & 164 & 29.7 \\
\hline -forward bending $>45^{\circ}$ & - & - & - & - & - & - \\
\hline -Backward bending $>20^{\circ}$ & 59 & 18.9 & 17 & 7.05 & 76 & 13.8 \\
\hline $\begin{array}{l}- \text { Twisting }>20^{\circ} \\
\mathbf{c h i}^{2}=\mathbf{3 . 7} \mathbf{p}=\mathbf{0 . 1}\end{array}$ & 61 & 19.5 & 34 & 14.1 & 95 & 17.2 \\
\hline $\begin{array}{l}\text { Seated Posture: } \\
\text {-Sit/stand. }\end{array}$ & 44 & 14.1 & 19 & 7.9 & 63 & 113 \\
\hline $\mathrm{Z}=5.2 \quad \mathrm{p}=0.02 *$ & & & & & & \\
\hline Energy Expenditure: & & & & & & \\
\hline $\begin{array}{l}\text { - The operator required to walk more } \\
\text { than } 30 \mathrm{~m}^{2} / \text { minute, while carrying } \\
\text { more than } 150 \mathrm{gm}\end{array}$ & 42 & 13.5 & 24 & 9.9 & 67 & 12.1 \\
\hline $\begin{array}{l}\text { - The worker climb up and/or down re- } \\
\text { peatedly }\end{array}$ & 15 & 4.8 & 6 & 2.5 & 21 & 3.7 \\
\hline $\begin{array}{l}\text {-The worker bend or stop below the } \\
\text { knees/repeatedly }\end{array}$ & - & & - & _ & - & _ \\
\hline - A respirator worn & - & - & 12 & 4.9 & 12 & 2.1 \\
\hline $\begin{array}{l}\text { - The worker exposed to temperatures } \\
\text { more than } 32^{\circ} \\
\mathbf{c h i}^{\mathbf{2}}=\mathbf{1 8 . 9} \mathbf{p}=\mathbf{0 . 0 0 0 0 7 *}\end{array}$ & - & - & - & - & - & - \\
\hline
\end{tabular}


Table (3): Monitoring of upper extremity movements during work of the studied workers

\begin{tabular}{|c|c|c|c|c|c|c|}
\hline \multirow[t]{2}{*}{ Posture } & \multicolumn{2}{|c|}{$\begin{array}{l}\text { Body shop } \\
(\mathrm{N}=312)\end{array}$} & \multicolumn{2}{|c|}{$\begin{array}{l}\text { Paint shop } \\
(\mathrm{N}=241)\end{array}$} & \multicolumn{2}{|c|}{$\begin{array}{c}\text { Total } \\
(\mathrm{N}=553)\end{array}$} \\
\hline & $\mathrm{N}$ & $\%$ & $\mathrm{~N}$ & $\%$ & $\mathrm{~N}$ & $\%$ \\
\hline 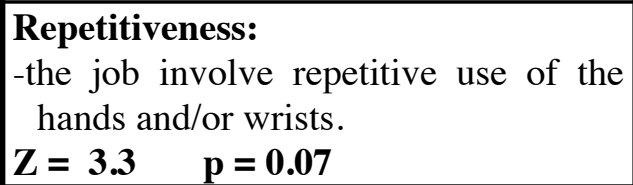 & 95 & 30.4 & 91 & 37.7 & 186 & 36.7 \\
\hline $\begin{array}{l}\text {-Mechanical Stress: } \\
\text { - hard or sharp objects, tools, or parts of } \\
\text { the work station put localized pres- } \\
\text { sure on a small area of the back or } \\
\text { side of the fingers or thumb. } \\
\text { - the palm or base of the hand used as a } \\
\text { striking tool, like a hammer. } \\
\text { chi }^{2}=\mathbf{0 . 3} \quad \mathbf{p}=\mathbf{0 . 5}\end{array}$ & 31 & 2.9 & 12 & 4.9 & 43 & 7.8 \\
\hline $\begin{array}{l}\text { Forces: } \\
\text { - the operator grip an object or a tool } \\
\text { which has a smooth, slippery surface. }\end{array}$ & 57 & 18.3 & 22 & 9.1 & 79 & 14.2 \\
\hline $\begin{array}{l}\text { - the tip of a finger or thumb used for } \\
\text { pressing or pushing. }\end{array}$ & 29 & 9.3 & 10 & 4.1 & 39 & 7.1 \\
\hline $\begin{array}{l}\text {-If the operator wears gloves, then, the } \\
\text { gloves hinder gripping. }\end{array}$ & 49 & 15.7 & 26 & 10.8 & 75 & 13.5 \\
\hline $\begin{array}{l}\text { - the worker push or pull objects or } \\
\text { tools weight } 300 \mathrm{gm} \text { or more by one } \\
\text { hand }\end{array}$ & 42 & 13.5 & 21 & 8.7 & 62 & 11.3 \\
\hline $\begin{array}{l}\text { - the operator grip or hold an objects or } \\
\text { tool which weighs more than } 200 \mathrm{gm} \\
\text { in one hand. } \\
\text { chi }^{\mathbf{2}}=\mathbf{1 . 5} \mathbf{p = 0 . 8}\end{array}$ & 19 & 6.1 & 9 & 3.7 & 28 & 5.1 \\
\hline $\begin{array}{l}\text { Posture: } \\
\text { - A pinch grip used }\end{array}$ & 27 & 6.8 & 13 & 5.4 & 40 & 7.4 \\
\hline - There wrist deviation & $\theta$ & - & - & - & - & - \\
\hline $\begin{array}{l}\text { - There twisting, rotating, or screwing } \\
\text { motion of the forearm. } \\
\text { chi }^{\mathbf{2}}=\mathbf{0 . 9} \quad \mathbf{p}=\mathbf{0 . 3}\end{array}$ & 51 & 32.7 & 36 & 14.9 & 86 & 15.6 \\
\hline $\begin{array}{l}\text { Tools or Hands-Held Objects: } \\
\text {-vibration from the tool or object trans- } \\
\text { mitted to the operator's hand. }\end{array}$ & 22 & 7.05 & - & - & 22 & 3.9 \\
\hline
\end{tabular}


Table (4): Incidence rate of work injuries among the studied workers duo to ergonomic causes during year (2006)

\begin{tabular}{|c|c|}
\hline $\begin{array}{c}\text { Work injuries } \\
\text { Total number }=9\end{array}$ & Ergonomic cause \\
\hline 1.Cut wound of head & $\begin{array}{l}\text {-Forward neck bending }>45 \text { «lead to struck by } \\
\text { sharp object }\end{array}$ \\
\hline 2.Cut wound of head & $\begin{array}{l}\text {-Lateral bending of neck }>20 \text { «lead to struck by } \\
\text { sharp object. }\end{array}$ \\
\hline 3.Cut wound of head & $\begin{array}{l}\text {-Twisting of neck }>20 \text { «lead to struck by sharp ob- } \\
\text { ject. }\end{array}$ \\
\hline 4.Head trauma & $\begin{array}{l}\text {-lying on back and backward bending of neck } \\
>20^{\circ}\end{array}$ \\
\hline 5. Right thumb fissure & $\begin{array}{l}\text { - Use hand for pushing heavy object lead to struck } \\
\text { by hard object. }\end{array}$ \\
\hline 6. Abrasions of right thumb & -Use thumb as a tool to press an object. \\
\hline 7.Cut wound of right hand & $\begin{array}{l}\text {-Repetitive use of hand and wrist lead to slipping } \\
\text { of hand and struck by sharp object }\end{array}$ \\
\hline 8.Cut wound in right hand & $\begin{array}{l}\text {-Part of work station put localized pressure on } \\
\text { palm of hand and repetitive use of hand. }\end{array}$ \\
\hline $\begin{array}{l}\text { 9.Cut wound in right index } \\
\text { finger }\end{array}$ & $\begin{array}{l}\text {-Repetitive use of the hands had led to struck by } \\
\text { hard object. }\end{array}$ \\
\hline $\begin{array}{l}\text { Incidence rate } / 100 \text { full time } \\
\text { workers/ year } 2006^{*}\end{array}$ & 1.2 \\
\hline
\end{tabular}

N.B All the injured cases were not wearing the personal protective devices

*.

- Mean working hours/day $=9$ hours

- Actually working days/year = 297 days

- Total number of examined workers $=553$

Please, refer to methodology for the applied equation 
Table (5): Distribution of musculoskeletal disorders among the Studied Workers

\begin{tabular}{|c|c|c|c|c|c|c|c|c|c|c|}
\hline \multirow[t]{2}{*}{$\begin{array}{l}\text { Musculoskeletal } \\
\text { Disorders }\end{array}$} & \multicolumn{2}{|c|}{$\begin{array}{c}\text { Body Shop } \\
(\mathrm{N}=312)\end{array}$} & \multicolumn{2}{|c|}{$\begin{array}{r}\text { Paint Shop } \\
(\mathrm{N}=241)\end{array}$} & \multirow[t]{2}{*}{$\bar{Z}$ test } & \multirow[t]{2}{*}{$P$ value } & \multicolumn{2}{|c|}{\begin{tabular}{|c|} 
Total num- \\
ber of cases \\
with MSDs \\
N=131
\end{tabular}} & \multicolumn{2}{|c|}{$\begin{array}{l}\text { Total num- } \\
\text { ber of exam- } \\
\text { ined cases } \\
\mathrm{N}=553\end{array}$} \\
\hline & $\mathrm{N}$. & $\%$ & $\mathrm{~N}$. & $\%$ & & & $\mathrm{~N}$. & $\%$ & $\mathrm{~N}$ & $\%$ \\
\hline $\begin{array}{c}\text {-Cervical disc } \\
\text { prolapse. }\end{array}$ & 33 & 10.6 & 18 & 7.5 & 1.6 & 0.2 & 51 & 38.9 & 51 & 9.2 \\
\hline $\begin{array}{l}\text {-Lumbosacral } \\
\text { disc prolapse }\end{array}$ & 31 & 9.9 & 26 & 10.8 & 0.1 & 0.7 & 57 & 43.5 & 57 & 10.3 \\
\hline -Osteoarthritis. & 19 & 6.1 & 12 & 4.9 & 0.3 & 0.6 & 31 & 23.7 & 31 & 5.6 \\
\hline - Hand/Arm pain & 17 & 5.4 & 14 & 5.8 & 0.03 & 0.8 & 31 & 23.7 & 31 & 5.6 \\
\hline $\begin{array}{c}\text {-Carpal tunnel } \\
\text { syndrome. }\end{array}$ & 9 & 2.9 & 6 & 2.5 & 0.08 & 0.7 & 15 & 11.4 & 15 & 2.7 \\
\hline -Tennis elbow. & 8 & 2.6 & 6 & 2.5 & 0.05 & 0.8 & 14 & 10.7 & 14 & 2.5 \\
\hline $\begin{array}{c}\text { Total number of } \\
\text { cases with MSDs }\end{array}$ & & & & & & & & & 131 & 23.7 \\
\hline
\end{tabular}

N.B One worker might have more than one Musculoskeletal disorder 
Table (6): Estimated Cost of musculoskeletal disorders/Person/Year 2006 among the affected workers.

\begin{tabular}{|l|c|}
\hline Type of cost & $\begin{array}{c}\text { Total number of } \\
\text { cases with } \\
\text { MSDs=131 } \\
\text { Cost (L.E.) }\end{array}$ \\
\hline Medical Cost: & 65500 \\
-Treatment of acute cases. & 7860 \\
-Referral cost. & 26200 \\
-Cost of investigations. & 34000 \\
-Cost of needed operations. & 133560 \\
Total & 310470 \\
\hline Wage Losses: & 43763 \\
-Time lost by workers need sick leave. & 354233 \\
\hline -Cost of Idle time of workers whose work is interrupted. & 310470 \\
Total & 140000 \\
\hline Associated Cost: & 22750 \\
-Surplus workers for replacement of discased employees. & 473220 \\
\hline -Compensation benefits paid to disabled worker after separation by the & 961013 \\
\hline fifth committee. & $7335.98(1287 \$$ ) \\
-Training replacement workers. & \\
Total & \\
\hline Grand total of cost & \\
\hline Cost/person/year (L.E.) & \\
\hline
\end{tabular}

N.B

L.E $=$ Egyptian pound

$\$=$ US Dollar 
Table (7): Assessment of Ergonomic Core Requirements inside the studied Plant

\begin{tabular}{|c|c|c|}
\hline \multicolumn{3}{|c|}{$\begin{array}{l}\text { Ergonomic core requirements } \\
\qquad \mathrm{N}=7\end{array}$} \\
\hline $\begin{array}{l}\text { Process Fully } \\
\text { Implemented } \\
3 / 7(42.8 \%)\end{array}$ & $\begin{array}{c}\text { Process partially } \\
\text { implemented } \\
2 / 7(28.6 \%)\end{array}$ & $\begin{array}{c}\text { No implementation } \\
\text { of process } \\
2 / 7(28.6 \%)\end{array}$ \\
\hline $\begin{array}{l}\text { 1-Plant follows a docu- } \\
\text { mented ergonomic pro- } \\
\text { cess. } \\
\text { 2-Proper work area lay- } \\
\text { outs and process layouts. } \\
\text { 3-Plant uses recognized } \\
\text { ergonomics evaluation } \\
\text { tools. }\end{array}$ & $\begin{array}{l}\text { 4-Ergonomic is considered } \\
\text { and addressed in the design- } \\
\text { in safety process. } \\
\text { 5-Plant always follows a pro- } \\
\text { cess to ensure prompt investi- } \\
\text { gation of and response to em- } \\
\text { ployee ergonomic concerns. }\end{array}$ & $\begin{array}{l}\text { 6-Plant regularly reviews jobs for } \\
\text { ergonomic risk factors and imple- } \\
\text { ments appropriate action plans. } \\
\text { 7-Job instructions are widely } \\
\text { in place to mitigate ergonomic } \\
\text { risk factors. }\end{array}$ \\
\hline
\end{tabular}


Table (8): Correlation coefficient between ergonomic risk factors and musculoskeletal disorders.

\begin{tabular}{|l|c|c|c|}
\hline \multicolumn{1}{|c|}{ Ergonomic risk factors } & $\begin{array}{c}\text { Lumber disc } \\
\text { prolapse } \\
\mathrm{N}=57 \\
(\mathrm{r})\end{array}$ & $\begin{array}{c}\text { Cervical disc } \\
\text { prolapse } \\
\mathrm{N}=51 \\
(\mathrm{r})\end{array}$ & $\begin{array}{c}\text { Hand/arm } \\
\text { pain } \\
\mathrm{N}=31 \\
(\mathrm{r})\end{array}$ \\
\hline -Trunk posture. & 0.7 & & \\
-Seated posture. & -0.3 & & \\
-Energy expenditure. & 0.2 & 0.6 & 0.8 \\
-Neck posture. & & & 0.4 \\
-Repititiveness. & & & 0.6 \\
-Mechanical stress. & & & 0.4 \\
-Forces. & & & 0.1 \\
-Posture of hand/arm. & & & \\
-Hands-Held objects. & & & \\
\hline
\end{tabular}

N.B One worker might have more than one complaint.

$0:<0.25$ : little or no correlation

$0.25:<0.5$ : fair correlation

0.5:0.75: moderate correlation

$0.75+$ : strong correlation

( Saunders and Trapp, 1999) 


\section{Discussion}

This study found moderate correlation between neck posture and frequency of cervical disc prolapse $(\mathrm{r}=0.6)$ Table(8). On the other hand, it was found that $29.7 \%, 13.8 \%$ and $17.2 \%$ of the examined workers need frequent neck forward bending $>20^{\circ}$, neck backward bending $>20^{\circ}$ and neck twisting $>20^{\circ}$ respectively Table(2). Also, it was found that $9.2 \%$ of the examined workers (represents $38.9 \%$ of workers with MSDs) were suffering from cervical disc prolapse. Table(5). These finding might claim that ergonomic neck stressors are risk factors of cervical disc prolapse. This coincides with Schierhout et al., 1995 who reported that ergonomic exposures in the workplace were significantly associated with musculoskeletal pain of the neck. Kristensen and Jensen, 2005 who studied the effect of ergonomic conditions as prognostic factors for symptoms in Denmark reported that $39 \%$ of the symptomatic workers (suffering from neck pain) were exposed to ergonomic stressors. Also, Esmail, 1996 reported that; neck extension during the work among maintenance workers of the aerial electrical network in Alexandria City, Egypt was associated with high prevalence rate of cervical spondylosis $(22.4 \%)$.
The present study reported that $49.2 \%$, $43.1 \%$ and $11.8 \%$ of the examined workers were subjected to duties needing trunk twisting, trunk forward bending and trunk backward bending respectively table(2). Also $27.6 \%$ and $21.7 \%$ of the examined workers were subjected to work need squatting and standing stationary respectively table(2). This could be explain the high prevalence rate $(43.5 \%)$ of lumbosacral disc prolapse among the workers with MSDs which represents $10.3 \%$ of the total examined workers table (5), this in addition to moderate correlation between trunk posture and lumbosacral disc prolapse $(\mathrm{r}=$ $0.7)$. But the present study found a negative correlation between seat posture and lumbosacral disc prolapse $(\mathrm{r}=-0.3)$ table (8). These results might claim that exposure to trunk ergonomic stressors could be a risk factor of lumbosacral disc prolapse while seated posture was not considered as a risk factor for lumbosacral disc prolapse. This coincides with Riihimaki, 1991 who concluded that; several ergonomic trunk stressors are related to low back disorders. Also, Beek and Dresen, 1998 after reviewing some studies on ergonomic epidemiology, they concluded that exposure to harmful working postures especially at trunk level may lead to lumbosacral disorders. 
The present study found a weak correlation $(r=0.2)$ between energy expenditure activities and frequency of lumbosacral disorders while it found a negative correlation with cervical disorders $(-0.1)$ and hand/arm pain (-0.3) table(8). This could be explained by the low frequency of activities which need energy expenditure inside the workplace table(2). So, the present study might claim that energy expenditure activities have low risk for lumbosacral disorders and no risk for cervical disc disorders and also for hand/arm pain.

The present study revealed that hand/ arm pain was strongly correlated $(\mathrm{r}=0.8)$ with repetitiveness, moderately correlated $(\mathrm{r}=0.6)$ with forces and fairly correlated with mechanical stress and posture of hand/arm $(r=0.4)$ table(8). Also, it was noticed that $23.7 \%$ of workers with MSDs were complaining of hand/arm pain. So, the present study might claim that combined ergonomic stressors could lead to hand/arm pain. This coincides with Punnett et al., 2004 who reported that musculoskeletal disorders of upper extremities were strongly associated with exposure to combined ergonomic stressors. Punnet, 1998 reported that $22 \%$ of workers with MSDs were complaining of symptoms related to wrists or hands and they were ex- posed to upper extremity ergonomic stressors.

It was noticed in the present study that all examined workers were exposed to long working hours/w $(56 \mathrm{~h} / \mathrm{w})$ for long duration (5:22 years). This could be a risk factor of MSDs as they do repeated activities inside the workplace with exposure to multiple ergonomic stressors. This coincides with Guo, 2002 who concluded that the number of hours spent on repeated activities at work was associated with the prevalence rate of back pain.

The present study found that $11.4 \%$ of workers with MSDs (represent $2.7 \%$ of all examined workers)were complaining carpal tunnel syndrome. This finding lower than reported in Ofverholm and Zetterberg, 1999 who reported that (3.4\%) of workers in car assembly were complaining of carpal tunnel syndrome. Also, the present study found $10.7 \%$ of cases with MSDs (represent $2.5 \%$ of examined workers) were diagnosed as tennis elbow cases. This could be explained by the frequent upper extremity ergonomic stressors found in the present study table (3) and to lesser extent exposure to vibration above TWA level table (1). This coincide with (Andersen and Haahr, 2003) who studied the cases of tennis elbow referred from general practice in Denmark and concluded that; 
cases of tennis elbow were associated with non-neutral postures of hand and arms, use of heavy held tools and high physical strain measured as a combination of forceful work, no neutral posture of hands and arms and repetition but they found the role of vibration was less consistent.

The present study found that only 1.2/ 100 fulltime workers/year 2006 were affected by injuries due to ergonomic causes. D'Errico et al., 2006 reported that 7.2/ 100 fulltime workers were affected by injuries duo to ergonomic stressors in Massachusetts, USA. The high incidence rate in the American study above the finding in the present study could be referred to the long period of study 5 years versus one year in the present study. Dembe et al., 2005 recommended ergonomic strategies to prevent work injuries which include changes in scheduling practices, job redesign, and health protection programs for people working in jobs involving overtime and extended hours.

The present study described the cost of musculoskeletal disorders among the examined workers. It was 7335.98 L.E (1287\$)/ person/year. Comparison of cost with another studies is difficult because of the difference in the health care system, compensation patterns and coverage, com- ponents of costs included and workforce and industries studied (Alamgir et al., 2007).

The present study found that body shop workers were exposed to carbon monoxide above TWA level while workers in paint shop were exposed to heat, and thiner above TWA level. These agents might be responsible for body fatigue and decreasing the vital capacity of the exposed workers. It was reported that whole body fatigue occurs when the combined metabolic demands of working muscles throughout the body exceed the capacity of cardiovascular and pulmonary systems to deliver oxygen to working muscles and to remove products of metabolism. This effect increases with intensity and duration of work activities (Keyserling and Armstrong, 1992). Also, the present study found noise level above TWA inside the workplace of body shop. This might distract the workers from their jobs and facilitates to cause injuries. Rempel and Janowitz, 1997 stated that loudness is directly related to the mechanical pressure transmitted to eardrum. Lower frequencies are more likely to produce hearing impairments while high frequencies are more likely to interfere with concentration and thought processes. This might predispose to injuries especially when ergonomic stressors are found. 
The present study found that only $42.8 \%$ of the ergonomic core requirements were implemented inside the studied factory (table 7). This might be a root cause for development of the ergonomic risk factors reported in the present study.

\section{Conclusion:}

MSDs of neck were strongly associated with combined neck ergonomic stressors. Hand/Arm pain was strongly associated with repetitiveness and pushing forces. Lumbosacral disorders were strongly associated with combined trunk ergonomic stressors. energy expenditure activities have low risk for lumbosacral disorders and no risk for cervical disc disorders and for hand/arm pain. The prevalence rate of MSDs was $23.7 \%$, incidence rate of injuries due to ergonomic causes/ 100 full time workers/ year 2006 was 1.2 and It was estimated that the cost of MSDs/ person/year was about 7300 L.E. (1287\$).

\section{Recommendation:}

Regular review of ergonomic risk factors of different jobs inside the vehicle assembly plants and implementation of appropriate action plans.

\section{References:}

1. Alamgir H, Tampa E, Koehoom M, Ostry A and Demers P (2007): Costs and comparison of work-related injuries in British Columbia Sawmills. Occup. Environ. Med.; 64: 196-201.

2. Andersen J and Haahr J (2003): Physical and psychological risk factors for lateral epicondylitis: a population based case-referent study. Occup. And Environ. Med.; 60: 322-329.

3. Beek A and Dresen M (1998): Assessment of mechanical exposure in ergonomic epidemiology. Occup. Environ. Med.; 55: 291-299.

4. Bhattacharya A, McGlothlin JD and Breck D (1996): Occupational ergonomics. Appendix B. New York, NY: Marcel Dekker, Inc., pp. 783802.

5. D' Errico A, punnett L, Cifuentes M, et al., (2006): Hospital injury rates in relation to socioeconomic status and working conditions. Occup. Environ. Med. doi: 10.1136/oem.

6. Dembe A, Erickson J, Delbos R and Banks S (2005): The impact of overtime and long work hours on occupational injuries and illnesses: New Evidence from the United States; 62: 588597.

7. Esmail A (1996): Cervical spondylosis among maintenance workers of the aerial electrical network in Alexandria city: An ergonomic study. Bulletin of High Institute of Public Health; v26 n2 p311-320. 
8. Fransson C, Bystrom S and Kilbom A (1996): Characteristics of forearm- hand exposure in relation to symptoms among automobile assembly line workers. Am. J. Ind. Med.; 29:15-22.

9. Guo H (2002): Working hours spent on repeated activities and prevalence of back pain. Occup. and Environ. Med.; 59: 680-688.

10. Keyserling W and Armstrong T (1992): Ergonomics. In textbook: Environmental and Occupational Medicine. 2ed edition. Edited by William Rom. P.1191-1193.

11. Keyserling WM, Brouwer M., and Silverstein BA (1992): A checklist for evaluating ergonomic risk factors resulting from awkward postures of the legs, trunk and neck. Int. J. Ind. Ergonomics; 9:283-301.

12. Keyserling WM, Stetson BA, Silverstein BA and Brouwer ML (1993): A checklist for evaluating ergonomic risk factors associated with upper extremity disorders. Ergonomics; 36 (7):807-831.

13. Kristensen B and Jensen C (2005): Self-reported workplace related ergonomic conditions as prognostic factors for musculoskeletal symptoms. Occup. Environ. Med.; 62: 188-194.

14. Kroemer, K.H.E. (1997): Fitting the Task to the Human, Fifth Edition, New York: Taylor \& Francis. General comment: covers work physiology, hand tools environment.

15. Kuorinka I and Forcier L (1995): Health and risk factor surveillance for work-related musculoskeletal disorders. Chapter 5. Work-related mus- culoskeletal disorders (WMSDs): a reference book for prevention. Taylor and Francis (1900 Frost Road, Suite 101, Bristol, PA 19007).

16. Lifshitz Y and Amstrong I. (1986): A design checklist for control and prediction of cumulative trauma disorders in hand intensive manual jobs. Vol. 2. Proceedings of the 30th Meeting of the Human Factors Society, Daytona, pp. 837841.

17. Mattioli S, Brillante R, Zanardi F and Bonfiglidi R (2006): Occupational and non-occupational risk factors for musculoskeletal disorders. Medicina del Lavoro; 97(3): 529-534.

18. Ministry of industry (2007): Car assembly in Egypt. Internal report, Cairo.

19. NIOSH (1997): Elements of ergonomic programs. General Ergonomic Risk Analysis Checklist. (NIOSH) publication No.97-117, National Institute for Occupational Safety and Health.

20. Ofverholm T and Zetterberg C (1999): Carpal tunnel syndrome and other wrist/hand symptoms and signs in male and female car assembly workers. International Journal of Industrial Ergonomics; Vol 23, Issue 3, p.193-204.

21. Punnett L (1998): Ergonomic stressors and upper extremity disorders in vehicle manufacturing. Cross sectional exposure response trends. Occup. Environ. Med.; 55: 414-420.

22. Punnett L, Gold J, Katz J, Gore R and Wegman D (2004): Ergonomic stressors and upper extremity musculoskeletal disorders in automobile 
manufacturing: a one year follow up study. Occup. Environ. Med.; 61: 668-674.

23. Rempel D and Janowitz I (1997): Ergonomic \& the prevention of occupational injuries. In textbook "Occupational \& Environmental Medicine. 2ed ed. Edited by Joseph LaDou. A LANGE medical book.

24. Riihimaki H (1991): Low-back pain: its origin and risk indicators. Scand. J. Work. Environ. Health; 17: 81-90.

25. Saunders and Trapp (1999): Summarizing data. In textbook "Basic and clinical biostatistics". A LANGE Medical book. P 54:56
26. Schierhout G, Meyers J and Bridger R (1995): Work related musculoskeletal disorders and ergonomic stressors in the South African workforce. Occupational and Environmental Medicine; 52: 46-50.

27. Waehrer G, Leigh J, Cassady D, etal, (2004): Costs of occupational injury and illness across states. J. Occup. Environ. Med.; 46: 1084-95.

28. Weil D (2001): Valuing the economic consequences of work injury and illness: a comparison of methods and findings. Am. J. Ind. Med.; 40:418-37. 